\title{
A Unique Case Study of Tree Plantation Bringing Increased Forest Cover to Puerto Princesa, Philippines
}

\author{
Dimithri Devinda Jayagoda ${ }^{1}$ \\ ${ }^{1}$ Graduate School of Asia Pacific Studies, Ritsumeikan Asia Pacific University, Oita, Japan \\ Correspondence: Dimithri Devinda Jayagoda, Graduate School of Asia Pacific Studies, Ritsumeikan Asia Pacific \\ University, Oita, Japan. Tel: 81-90-4480-9072. E-mail: mostlyibeleiveinmyself@gmail.com
}

Received: October 22, 2014 Accepted: November 21, 2014 Online Published: January 28, 2015

doi:10.5539/jsd.v8n1p138

URL: http://dx.doi.org/10.5539/jsd.v8n1p138

\begin{abstract}
Former mayor Edward Hagedorn has set his vision "To see Puerto Princesa as model city in sustainable development." This paper discussed how people have comitted to accomplish this vision and also how they have contributed to recognize Puerto Princesa City as the City in the Forest in Philippines. The objective of this study was to describe, through the use of selected case study, how community based forest management is best practiced while protecting and rehabilitating the forest in the Puerto Princesa City of Palawan. 'Feast of the Forest' annual tree planting project is discussed as a case study. Local community, policy makers, academia and politicians of the city have clearly described that the community is fully aware about forestation, protection and environmental security in the city. Research findings further prove that forest cover in Puerto Princesa has increased by year 2010 compared to 1992 records.
\end{abstract}

Keywords: community, forestation, forest management, involvement, leadership, participation

\section{Introduction}

Community participation in tree planting activities is a common occurrence in the city of Puerto Princesa in Palawan the Philippines, known as the City in the Forest. Honorable Mayor (former) Edward Hagedorn initiated several projects to accomplish his vision "To see Puerto Princesa as model city in sustainable development." All these projects give high emphasis to protecting the environment. Puerto Princesa, with a land area of 253,982 hectares, boasts a forest cover of about 73 percent and the city is home for a population of 225,955 (City Information, 2010). The local community is keen and committed to protecting the environment. Due to the efforts of the community and reliable leadership, Puerto Princesa City was declared the first Carbon Neutral city by the Association of Southeast Asian Nations (ASEAN). Puerto Princesa is not only carbon neutral, but also a significantly carbon negative city. Before discussing the forest plantation and management story of Puerto Princesa, it is important to investigate the current global and country (Philippines) status of forests.

\subsection{Dwindling Forests Around the World}

The term "forest" is defined as "land spanning more than 0.5 hectares with trees higher than 5 meters and a canopy cover of more than 10 percent, or trees able to reach these thresholds in situ. It does not include land that is predominantly under agricultural or urban land use" (Food and Agriculture Organization [FAO] 2010). FAO 2012 report recorded that global forest is 30 percent of global land area and amounts to 3.8 billion hectares. The report also notes that "there was a net decrease in global forest area of 1.7 percent between 1990 and 2005, at an annual rate of change of 0.11 percent. This equates to an annual shift from forest land use to other land uses of 3 million hectares per year between 1990 and 2000 and of 6 million hectares per year between 2000 and 2005." One percent or more reduction per year of the forest is recorded in thirty-seven countries and areas, and ten countries that had the highest annual net negative change rates for 2000-2005 are: Comoros (-7.4 percent); Burundi (-5.2 percent); Togo (-4.5 percent); Mauritania (-3.4 percent); Nigeria (-3.3 percent); Afghanistan (-3.1 percent); Honduras (-3.1 percent); Benin (-2.5 percent); Uganda (-2.2 percent) and the Philippines ( -2.1 percent) (FAO 2006).

The Food and Agricultural Organization in 2000 defined "forest degradation" as "changes within the forest which negatively affect the structure or function of the stand or site, and thereby lower the capacity to supply products and/or services." FAO 2010 defined "deforestation" as "the conversion of forest to other land use or the 
long-term reduction of the tree canopy cover below the minimum 10 percent threshold." When forest cover is compared in 1990 and 2005 it is clear that the total global, total Asia and South and Southeast Asia are showing a decline, as shown in figure 1. Again, in a regional comparison, in same years Eastern and Southern Africa, Northern Africa, South and Southeast Asia, Central America, North America, Oceania and South America shows a negative change while East Asia, Western and Central Asia, Europe and Caribbean regions shows a growing trend, as shown in figure 2.

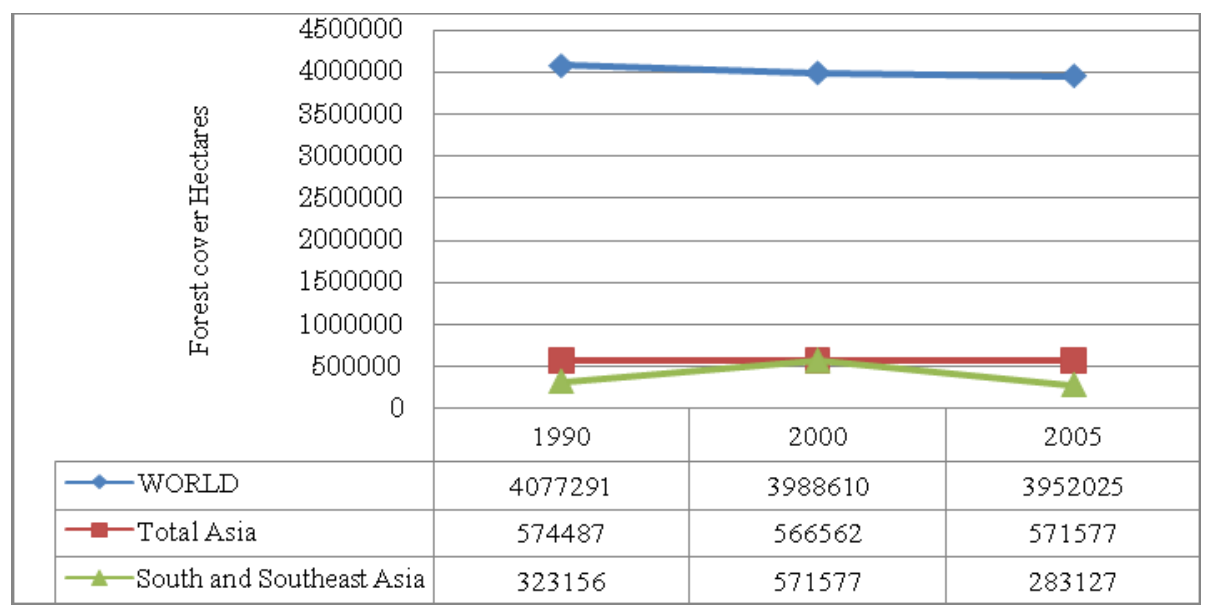

Figure 1. Forest covers comparison of World, Asia and South and Southeast Asia 1990-2005

Source: Created by the author, based on FAO 2010 data

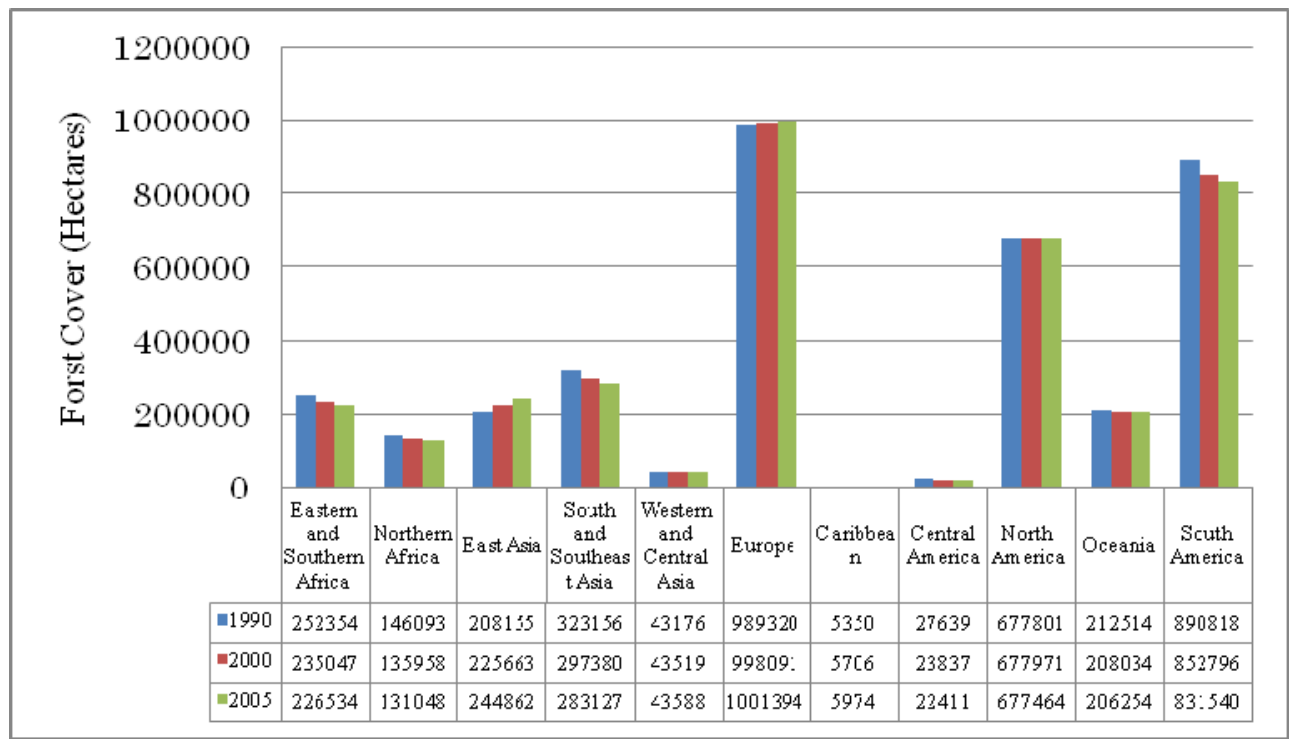

Figure 2. Forest cover comparison of the regions 1990-2005

Source: Created by the author, based on FAO 2010 data

\subsection{Status of Forests in the Philippines}

It is recorded that in 1521 Philippines was rich with its forest cover of 27 million hectares, which counted for 90 percent of the total land area (Lascoet al., 2001, Rebugio et al., 2007). This was the time that Spanish colonizers entered the country. Figure 3 shows the forest degradation in Philippines with the 27 million hectares being reduced to 7.17 million hectares. When Spanish conquered Philippines in the middle of the sixteenth century, the country had 90 percent of forest cover (Westoby, 1989). In 1900 when Americans replaced Spanish, forest cover was 21 million hectares, or 70 percent coverage (Garrity et al., 1993, Liu et al., 1993, Rebugio et al., 2007). Modern logging operations were introduced to the country by Americans and as a result Philippines mahogany was introduced and led the world market (Rebugio et al., 2007). American colonial records show that by the year 1920 the country had 19 million hectares of forest, covering 64 percent (Bautista, 1990). By the year 1940, there 
were 163 sawmill and logging companies in Philippines, with about 41 percent of them owned by Americans and 34 percent owned by the elite class of Philippines (Cruz, 1941).

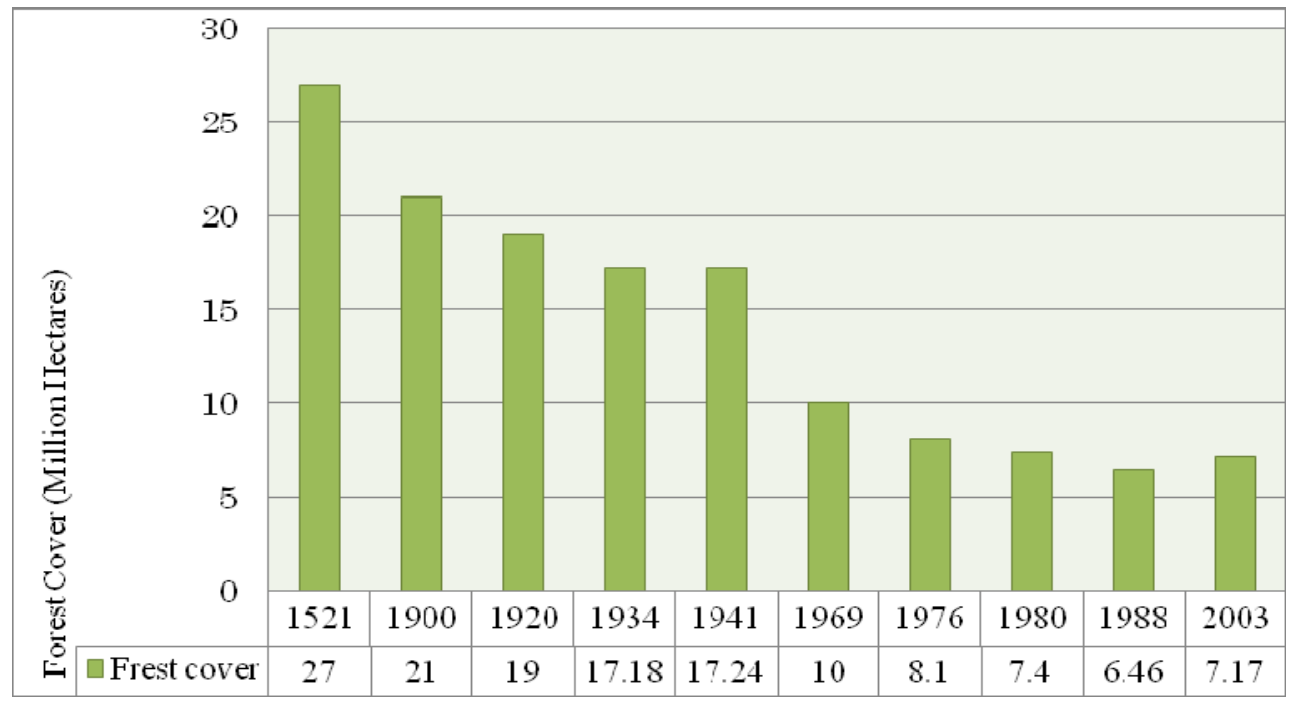

Figure 3. Forest cover of Philippines 1521 - 2003

Source: Rebugio et al.2007, Lasco et al. 2001, Garrity et al. 1993, Liu et al. 1993, and Bautista1990

Above figure 3 shows historic forest cover loss from 1521 to 2003, as presented by Forest Management Bureau in 2005. During the period 1900 to 1941 there was an average of 92,000 hectares of forest lost, amounting to about 4 million hectares during these four decades (Rebugio et al., 2007). By the year 1959 Philippines was recorded as the major tropical timber exporter and was holding a share of one third in the world market (Quintos, 1989; Rebugio et al., 2007). Between 1945 and 1953 Philippines experienced economic restructuring, focusing more on forest resources, resulting in massive exploitation and deforestation (FAO, 1989; Dawning et al., 1993). In 1969 the forest cover was recorded as 10 million hectares, but was further reduced to 6.46 million hectares by the year 1988 (Ganapin, 1987; Bautista, 1990). Rebugioet al. 2005 suggested that during the last century Philippines annual deforestation fluctuated around an average 150,000 hectares per year. In early 1970 s, annually about 170,000 hectares of forest land were destroyed in Philippines (Bunge, 1984). Protection, rehabilitation and development of forest land were introduced in late 1970's to replace timber harvesting and utilization (Dawning et al., 1993). Studies conducted by FAO in 1990, 2000 and 2005 show that the forest cover in the whole country is reduced to 7.162 million hectares, as shown in figure 4.

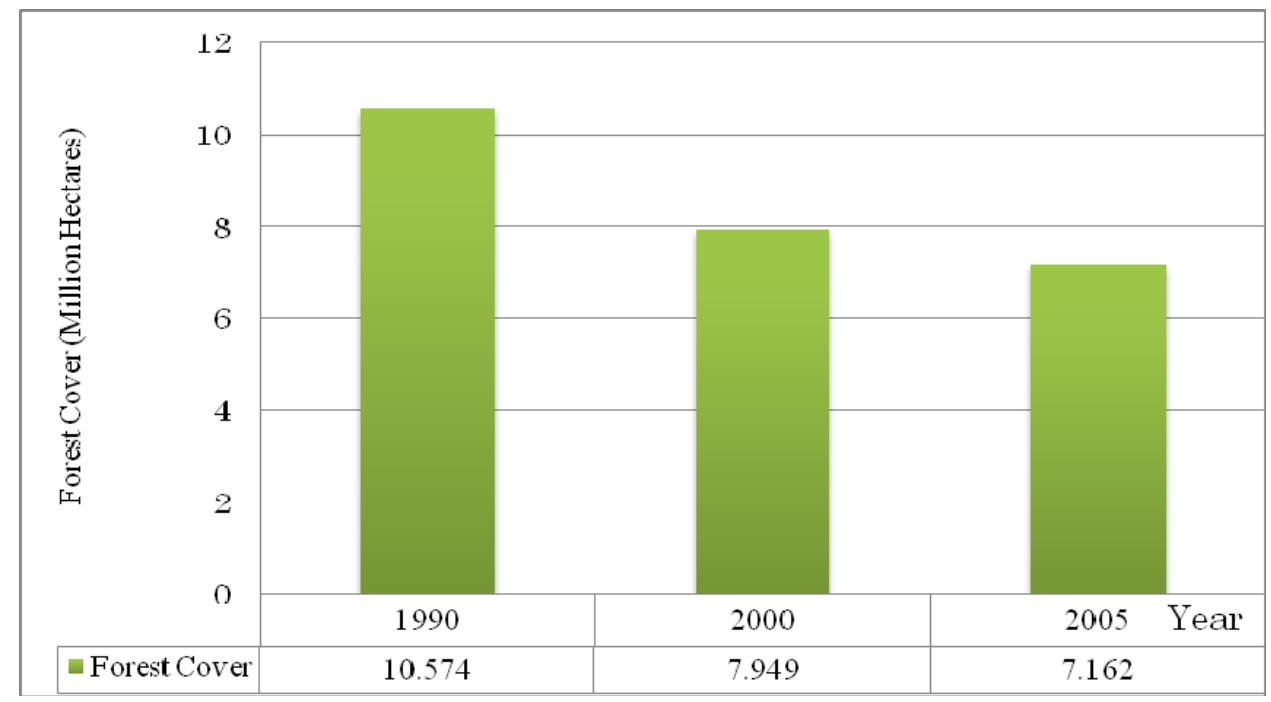

Figure 4. Forest cover of Philippines 1990-2005

Source: Created by the author, based on FAO 2010 data 


\subsection{Forest Degradation in Philippines}

Guiang et al. 2001 note that forest degradation in the Philippines is often attributed to two factors: poverty, with high upland population growth, and de facto management and openaccess (quoted by Kummer, 1992). Ooi 1987 gives the following reasons for Philippines' deforestation: shifting cultivation, unorganized encroachment on forest lands, squatting, migration of landless lowlanders into upland forested areas, and government-sponsored settlement schemes. Kummer 1992 identifies the rootcauses of deforestation in the Philippines. He states key factors that caused deforestation were both legal and illegal logging and expansion of agriculture. This trend can be seen especially in the post war era. He has described this in the format of a process, as shown in figure 5.

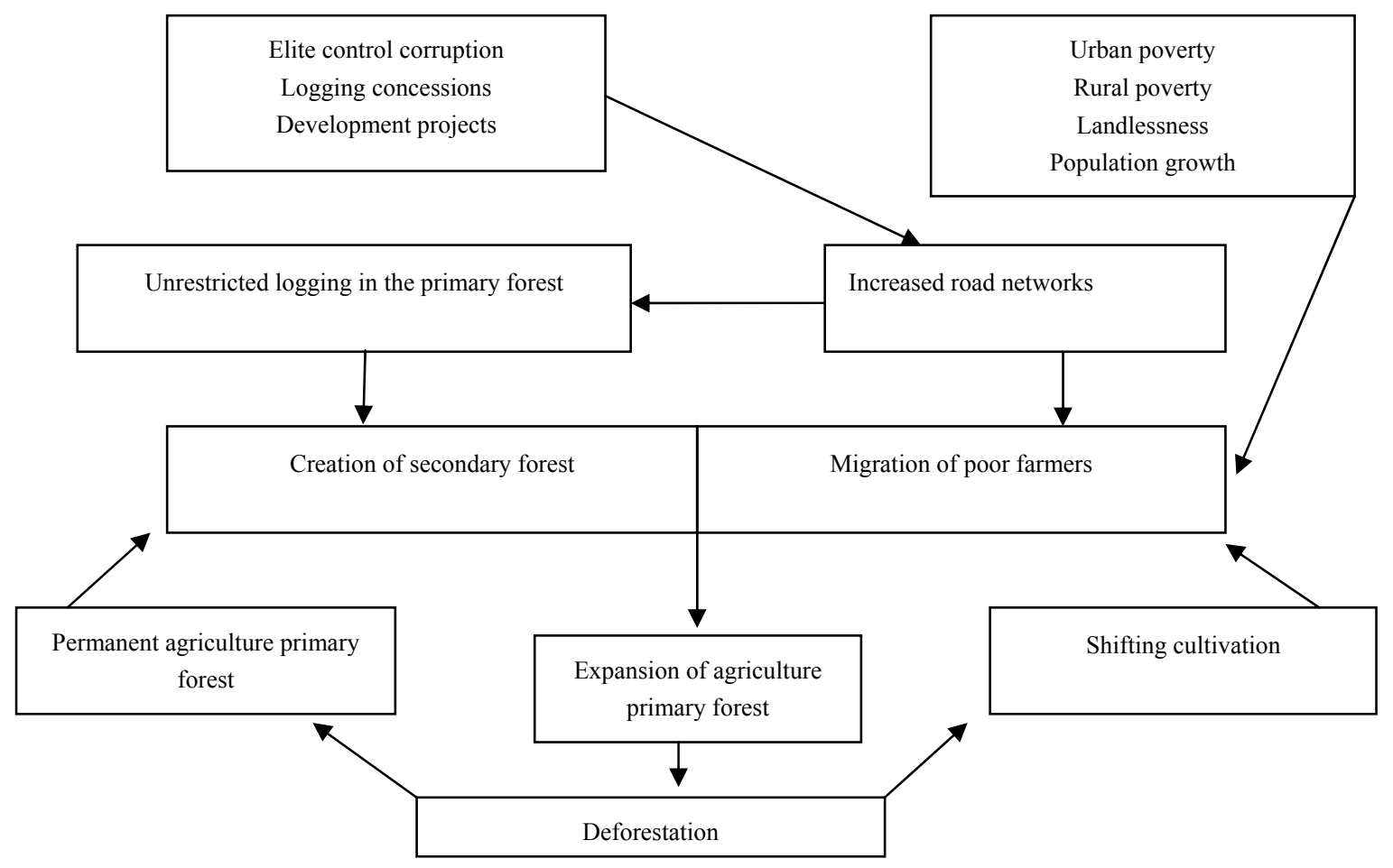

Figure 5. Deforestation process in the Philippines

Source: Kummer 1992

Rebugio et al. 2007 mentioned direct and underlying causes of forest decline in Philippines as shown in figure 6. Natural causes like environmental reasons, anthropogenic causes and agents (stakeholders), and related causes created by humans are listed under direct causes. Market failures, mistaken policy interventions, governance weaknesses, broader socioeconomic and political causes are mentioned as underlying causes. Community based forest management has been introduced and adopted in many developing countries in order to combat deforestation. This concept is adopted in developed countries, as an approach to sustainable management of forest. 


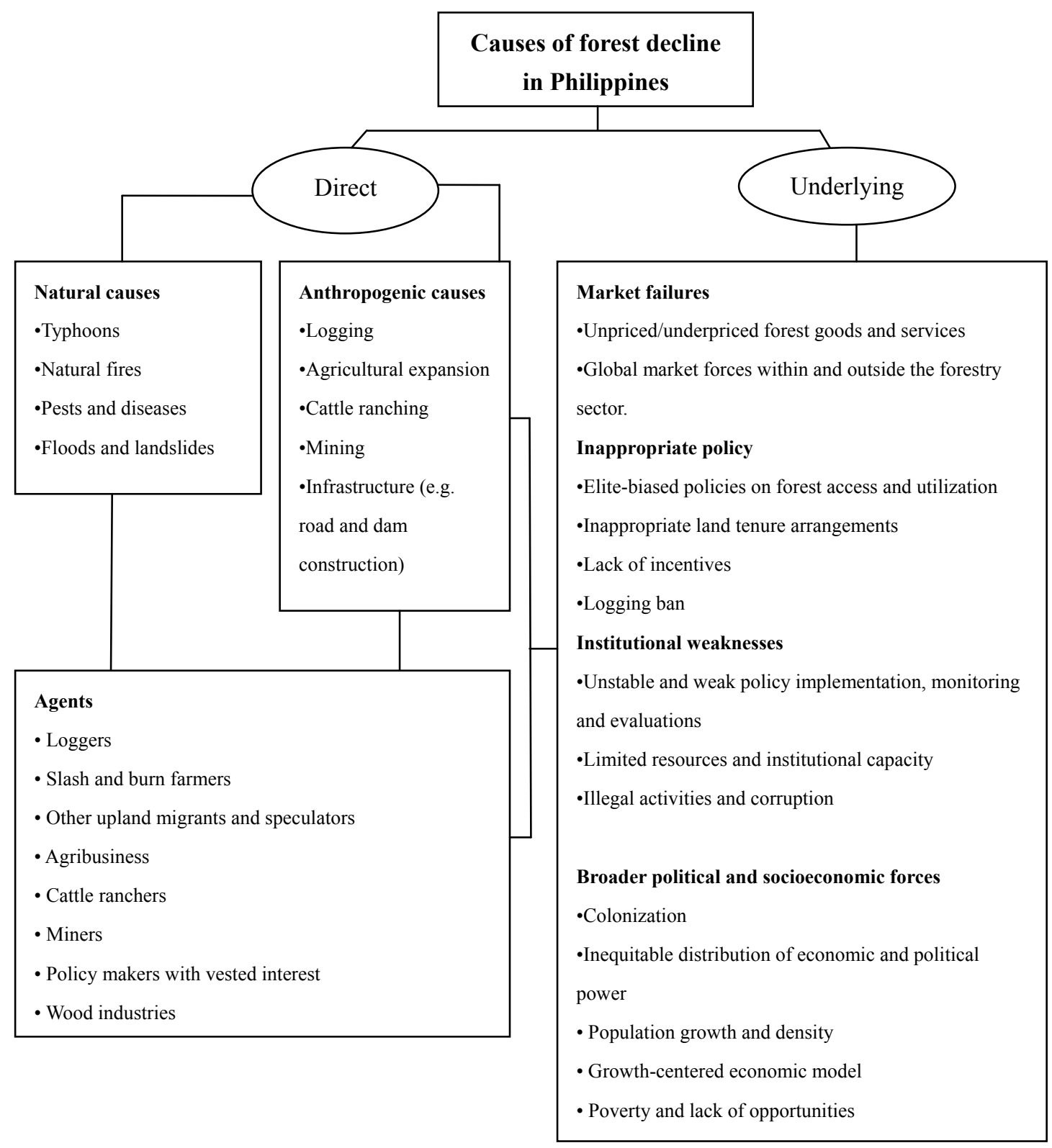

Figure 6. Causes of forest degradation in the Philippines

Source: Rebugio et al.2007, modified based on Contreras-Hermosilla 2000

\section{Community Based Forest Management (CBFM)}

Due to heavy loss of the forest globally, the concept of community participation and community involvement in forest management gained its recognition during the past few decades. 'Community Based Forest Management' (CBFM) is defined as "any situation that intimately involves local people in forestry activities" (FAO, 1978). This concept can include joint forest management, adaptive co-management, participatory action research, community-based resource management, and integrated resource management (Guillermo \& Prabhu, 2005). It is important to understand key words according to FAO 2010. 'Communities' are, "forest management rights and responsibilities are transferred from the public administration to local communities (including indigenous and tribal communities) through long-term leases or management agreements." A 'local community' is "forest owned by a group of individuals belonging to the same community residing within or in the vicinity of a forest area. The community members are co-owners that share exclusive rights and duties, and benefits contribute to the community development." Plantation of the trees with the local community is conducted through 'aforestation', that is, the "establishment of forest through planting and/or deliberate seeding on land that, until then, was not 
classified as forest," and 'reforestation', the "re-establishment of forest through planting and/or deliberate seeding on land classified as forest" (FAO, 2010). Community Based Forest Management has greatly gained global acceptance as a means of reducing and avoiding forest degradation, with community becoming the center. CBFM has appeared in the FAO publications 'Our Common Future' in 1987, 'Agenda 21' in 1992 and 'The Future We Want' in 2012. The keywords are highlighted and introduced as shown in box 1.

Box 1: International recognition of the concept

\section{Our Common Future - 1987}

3.4. - 71. Programmes to preserve forest resources must start with the local people who are both victims and agents of destruction, and who will bear the burden of any new management scheme. They should be at the centre of integrated forest management, which is the basis of sustainable agriculture.

\section{Agenda 21 - 1992}

11.4.b. Establishing linkages with other data systems and sources relevant to supporting forest management, conservation and development, while further developing or reinforcing existing systems such as geographic information systems, as appropriate;

11.13. d. Carrying out revegetation in appropriate mountain areas, highlands, bare lands, degraded farm lands, arid and semi-arid lands and coastal areas for combating desertification and preventing erosion problems and for other protective functions and national programmes for rehabilitation of degraded lands, including community forestry, social forestry, agroforestry and silvipasture, while also taking into account the role of forests as national carbon reservoirs and sinks;

11.14. d. Carrying out surveys and research on local/indigenous knowledge of trees and forests and their uses to improve the planning and implementation of sustainable forest management;

11.21. d. To promote more comprehensive use and economic contributions of forest areas by incorporating eco-tourism into forest management and planning.

12.17. $\mathrm{c}$ To increase the vegetation cover and support management of biotic resources in regions affected or prone to desertification and drought, notably through such activities as afforestation/reforestation, agroforestry, community forestry and vegetation retention schemes;

\section{The Future We Want - 2012}

193. "We highlight the social, economic and environmental benefits of forests to people and the contributions of sustainable forest management to the themes and objective of the Conference. We support cross-sectoral and cross-institutional policies promoting sustainable forest management".

"We call for increased efforts to strengthen forest governance frameworks and means of implementation, in accordance with the non-legally binding instrument on all types of forests, in order to achieve sustainable forest management. To this end, we commit to improving the livelihoods of people and communities by creating the conditions needed for them to sustainably manage forests, including through strengthening cooperation arrangements in the areas of finance, trade, transfer of environmentally sound technologies, capacity-building and governance, as well as by promoting secure land tenure, particularly decision-making and benefit-sharing, in accordance with national legislation and priorities".

196. We stress the importance of integrating sustainable forest management objectives and practices into the mainstream of economic policy and decision making, and to that end we commit to working through the governing bodies of member organizations of the Collaborative Partnership on Forests to integrate, as appropriate, the sustainable management of all types of forests into their strategies and programmes.

Source: Our Common Future 1987, Agenda 211992 and The Future We Want 2012.

Even though this concept has world recognition, it faces several challenges. Brown (2003) identifies three challenges to people-centered conservation efforts: (1) to incorporate the different understandings, meanings and values that stakeholders have in regards to biodiversity, the environment and nature; (2) to incorporate the plural knowledge, values and interests of the stakeholders in to the decision making process and; (3) to develop new institutions for conservation and development which are more flexible and adaptive than existing institutions. Despite the challenges, this concept is widely adopted throughout the Philippines. 


\subsection{Community Based Forest Management in the Philippines}

In the Philippines, community forestry has been regarded as a "new approach to forest management" (Department of Environment and Natural Resources-DENR 1989). In most cases community forestry has shown links to conservation biodiversity. FAO 2010 defines it as "forest area designated primarily for conservation of biological diversity. Includes but is not limited to areas designated for biodiversity conservation within the protected areas." Department of Environment and Natural Resources, Administrative Order No. 96-29 states that the Community Based Forest Management Agreement is a production-sharing agreement between the Department of Environment Natural Resources and the participating people's organization (POs) for a period of 25 years, renewable for another 25 years and shall provide tenurial security and incentives to develop, utilize and manage specific portions of forest lands. There are several government policies being implemented to increase CBFM activities in the Philippines. Government policies introduced since 1987 and their descriptions are mentioned in table 1. With the implementation of Executive Order (EO) 263 in 1995, the Philippines declared CBFM as its official mechanism to implement sustainable forest management, as an immediate response for effective action to minimize negative upstream-downstream and on-site, off-site impacts of forest management externalities (Wallace, 1993; Guiang et al., 2001).

Table 1. Government policies to adopt and implement CBFM

\begin{tabular}{lll}
\hline Year & Policy & Description \\
\hline 1987 & Constitution & Enjoins the state to enter into co-production, joint venture, or production \\
& & agreements vis-à-vis natural resource management with empowered \\
& Communities.
\end{tabular}

1987 Executive Order (EO) 192 Reorganizes the environment and the natural resource sector, and mandates the DENR to conserve, manage, develop, properly use, license, and regulate the use of natural resources.

1989 DENR Department Administrative Order (DAO) 123

1991 Local Government Code (LGC) of 1991 or RA 7160:

Promotes community participation in the rehabilitation, protection, improvement, and management of degraded and productive residual forests, brush lands, virgin forests, and marginal lands.

Devolves central government functions, such as the natural resource management functions of the DENR, to local government units (LGUs).

1992 National Integrated Protected Areas System (NIPAS) Act or RA 7586

Allocates forestlands and forest resources as protected area systems for purposes of biodiversity conservation, habitat preservation, watershed protection, and maintenance of ecological balance.

1995 Executive Order (EO) 263

1996 DENR Department Administrative Order (DAO) 96-29

Declares CBFM as the country's national strategy for sustainable forest management.

Provides the Implementing Rules and Regulations of EO 263; paves the way for the granting of resource use rights to communities; and allows the transfer of tenure as well as their limited division through such mechanisms as joint venture and contracting.

1997 DENR Memorandum Circular (MC) 97-12

Adopts the DENR Strategic Action Plan for CBFM.

1997 Indigenous People's Rights Act (IPRA) or RA 8371

Recognizes, protects, and promotes the rights of indigenous peoples, and paves the way for the individual or communal titling of ancestral forestlands.

Source: Guiang et al. 2001

\section{Method}

The main objective of this study was to describe, through the use of selected case study, how community based forest management is best practiced while protecting and rehabilitating forest in the Puerto Princesa City of Palawan. In order to achieve this objective, several questions were answered, using a mixed research methodology. What is the global and national (Philippines) level status of the forests? How do community stakeholders and their leadership contribute to implementation and development of community based tree planting and management projects in the city? How does community involvement contributed to ongoing 
environmental projects? How these, community based projects contributed to achieve the vision of the city?

Both qualitative and quantitative approaches were used in this study as a mixed methodology. Data were gathered from both secondary and primary sources. Data gathering techniques used in this study were desk research, interviews, case studies, observations, photography, focus groups, and surveys. The interviews were conducted at three different stages. Policy makers including former city mayor, the current city mayor, high ranked city hall staff and city environment office staff were interviewed individually. Focus group discussions and individual interviews were conducted with faculty members of the Palawan State University (PSU), Palawan Council for Sustainable Development (PCSD), city information, city planning and city agriculture offices. Three different questionnaires were used to interview people at different stages. Informal discussions and interviews were conducted among community leaders, university students, fishermen, tricycle drivers and participants at the Pist Y Ang Kagueban in 2013. The author participated in Pist Y Ang Kagueban annual tree planting project in 2013 and visited the planting sites and relevant offices in 2010, 2011 and 2013. Strict observations were made during these visits, and photography was used to record qualitative findings. Observations were conducted in planting sites and other related locations to gather more information. Notes were taken during informal discussions. Participatory research methods were used throughout the study. Video recording and photography were used to document findings.

\section{Case Study: Pista Y Ang Kagueban (PYAK) - Feast of the Forest}

This massive tree planting project was initiated by the staff of the Palawan Council for Sustainable Development (PCSD) in 1991. 'Pista Y Ang Kagueban' has attracted not only older citizens, but also to the younger community of the city, to be an instrument for combating global issues. To bring this great idea to the local citizens, a comprehensive information and education campaign was launched. There were about 2500 participants in the launch of the project. First year of the event recorded that 28,000 trees were planted, and the number has increased up to 140,000 trees in 2006, with the participation of around 30,000 locals (Graceffo, 2007). This project was launched to find a solution for the problem of water supply shortage. In the beginning the selected site of the project was Irawan watershed area. Pista Y Ang Kagueban schedules in June and United Nations declared, June as the environmental month.

In Barangay (Village) Irawan on $27^{\text {th }}$ of July 2013, the $23^{\text {rd }}$ tree planting campaign took place. Annually this event is scheduled on the 4th week of June. Due to change in administration with the appointment of new Mayor Hon. Lucilo Rodriguez Bayron, the project has moved to July. Around 4:00 a.m. in the morning locals gathered at the city coliseum. City government provided trucks to pick people and transport them up to the Irawan watershed to join planting activity. Some people arrived to the planting site even before 5:00 a.m. The gathering of locals at the site is shown in figure 7. An official suggested that more than 20, 000 people joined the planting activity that day.

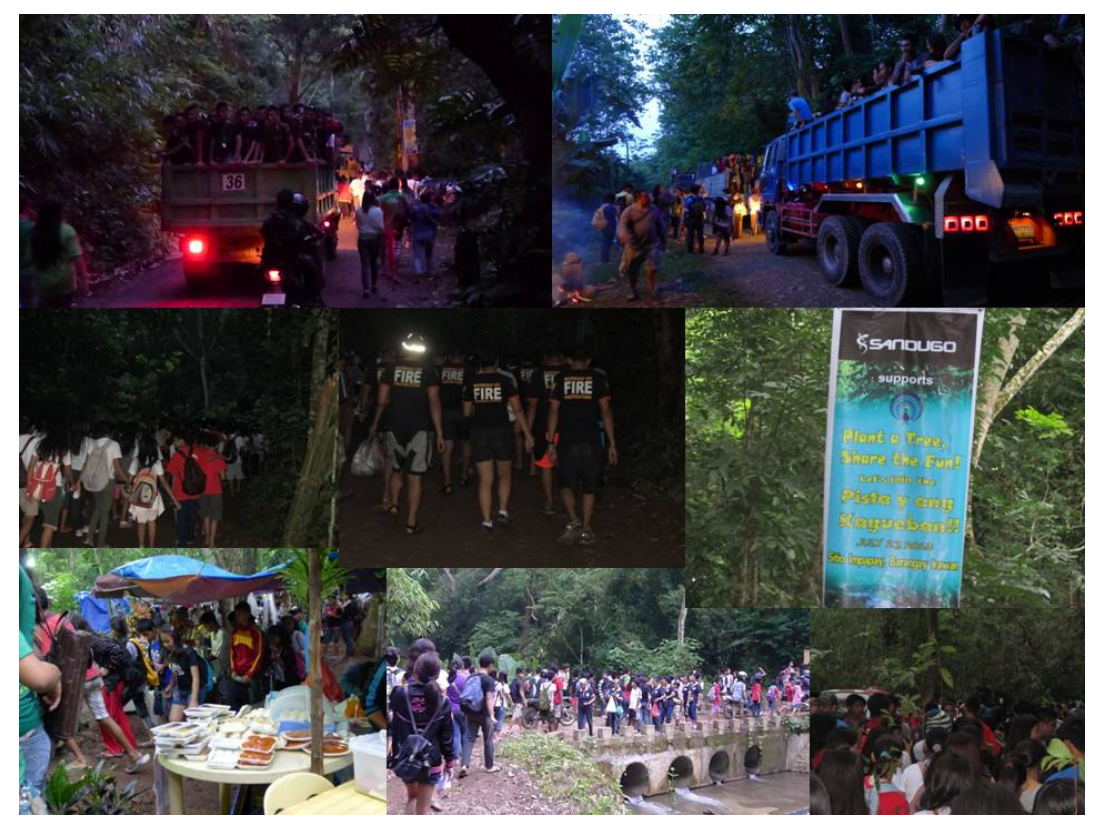

Figure 7. Local community reaching the planting site

Source: Author, Patrick 2013 
The planting event has included Batac and Tagbanwakatutubo dances, pop music, local talents, young TV celebrities, Miss Philippines-Earth beauties in shorts, and speeches of politicians (Javelosa, 2010). One of the differences of the 2013 event was that there was a represention of many local talents, instead of attracting nationally famous actors, actresses and beauty queens. There were several other events attached to the main planting event. Many gifts were given away by sponsors to those who answered general knowledge questions correctly. Palawan State University and other local university students performed music and dances to entertain. Speeches were given by the mayor, vice mayor, city environment officer and other local authorities, and they demonstrated planting, as shown in figure 8.

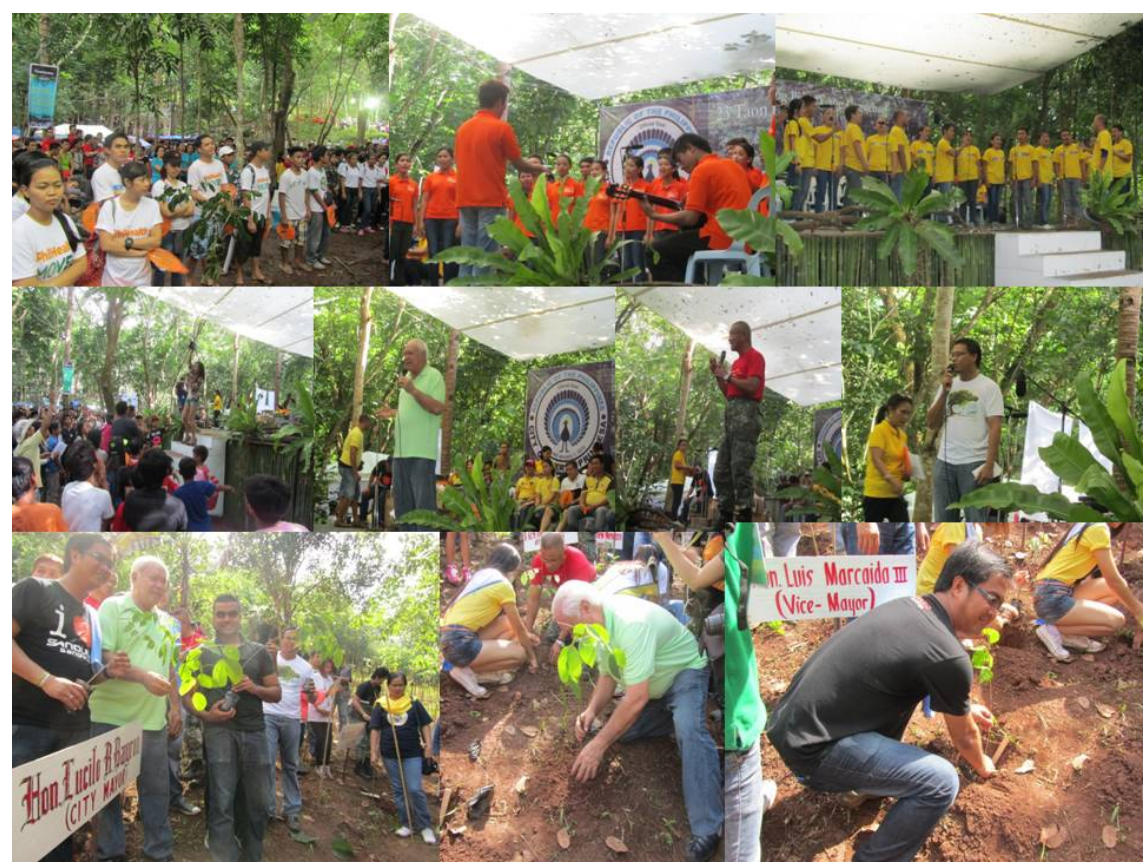

Figure 8. Local talents, speeches, and officials joining planting with mayor

Source: Author, Patrick 2013

Parallel to the Feast of the Forest, Boy Scouts and Girl Scouts all over Palawan joined for a camping activity from the day prior to the event. Scouts from various age groups joined this activity on the day of planting. This is one of the major attractions of the event, and the passion towards protecting the environment has been set in the minds of the young people since childhood. City environmental office is responsible for plant nursery, site selection, planning, implementation and all administrative activities of the event. Preparation and camping activities are shown in figure 9. 


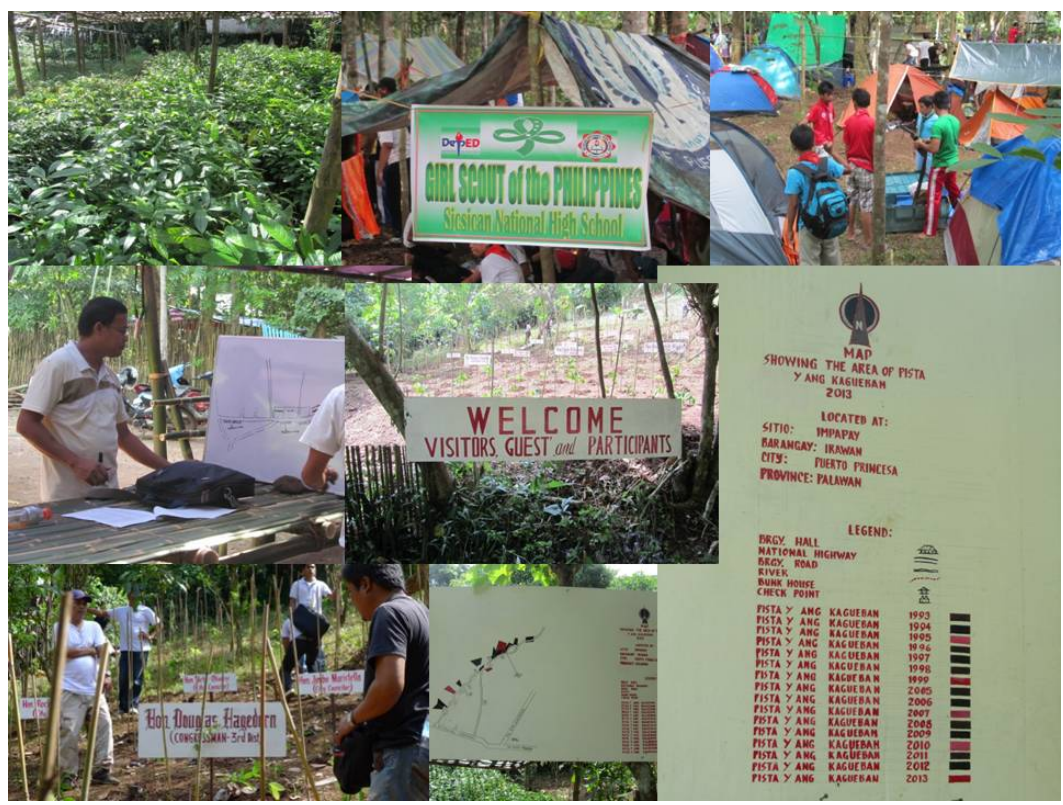

Figure 9. Site preparation and Scout camp

Source: Author 2013

In 2010 more than 50,000 people participated and many private companies willingly closed shop during morning hours to allow their employees to take part in the annual tree planting event spearheaded by a man with a vision, former mayor Hagedorn (Javelosa, 2010). Participating in these activities is a social function, and for some students it is a requirement for scholarship. Environmental friendliness is "a way of life" for citizens in Puerto Princesa. Students representing various groups and they wear special t-shirts on the day to express their understanding about the environment, as shown in figure 10.

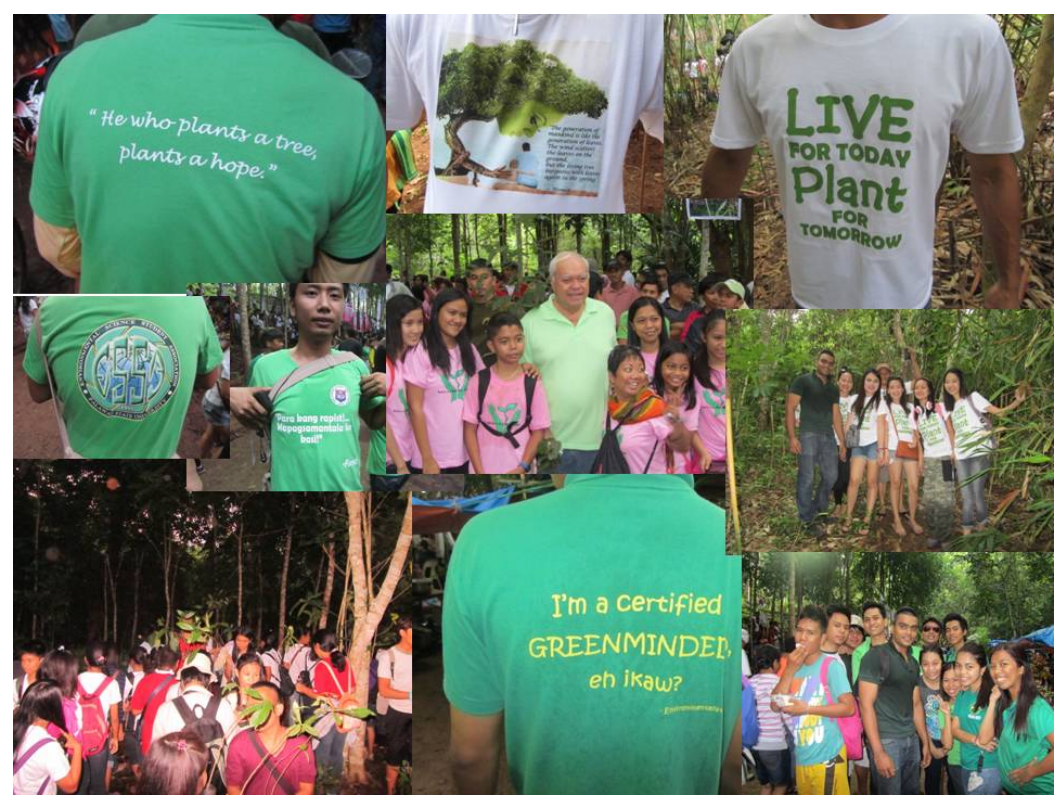

Figure 10. Different groups represented with messages on their t-shirts

Source: Author, Patrick 2013

By the $20^{\text {th }}$ year of the tree planting campaign, two million hardwood and indigenous trees had been planted (Javelosa, 2010). Government forest rangers are making sure that trees are growing well and, at the same time, inspecting for illegal logging. Montenegro 2012 states, "Puerto Princesa, Palawan, two million trees were 
planted by the up to 60,000 people who flocked to the mountains of Irawan on Saturday to celebrate Puerto Princesa's Pista Y Ang Cagueban." Since its implementation, the Feast of the Forest has resulted in the planting of closely to two million trees that resulted in Puerto Princesa City being covered in green (Graceffo, 2007). The number of planted trees increased throughout the years and city government received the support from its stakeholders: schools, colleges, fraternities, civic organizations, government employees, military, NGOs, as well as Boy and Girl Scouts. Even support has been extended by prisoners of the local jail and foreign tourists (Graceffo, 2007).

\section{Discussion}

Information and Education Campaign (IEC) was strengthened and appealed to all barangays. An organizing committee, chaired by the city vice mayor, supervised all the kagueban (event) activities (arrangement of transportation for participants; security and safety; recreation; accessibility of the site; and other related activities), with coordination with other government offices and the private sector. During the past two decades, planted species were: Big-leaf Mahogany (Swieteniamacrophylla), Manguim (Acacia manguim), Gmelina (Gmelinaarborea), Fire Tree (Delonixregia), Narra (Pterocarpusindicus), Ipil (Instiabijuga), Agohodel Monte (Casuarinaequisitifolia), Malugai (Pometiapinnata), Amugis (Koordersiodendronpinnatum), Balayong (Prunusjavanica), Acacia (Samaneasaman), Falcata (Mollucansau) (City Environment Office 2011). During the tree plantation projects, total area planted is shown in figure 11 and estimated numbers of seedlings planted in the project are shown in figure 12.

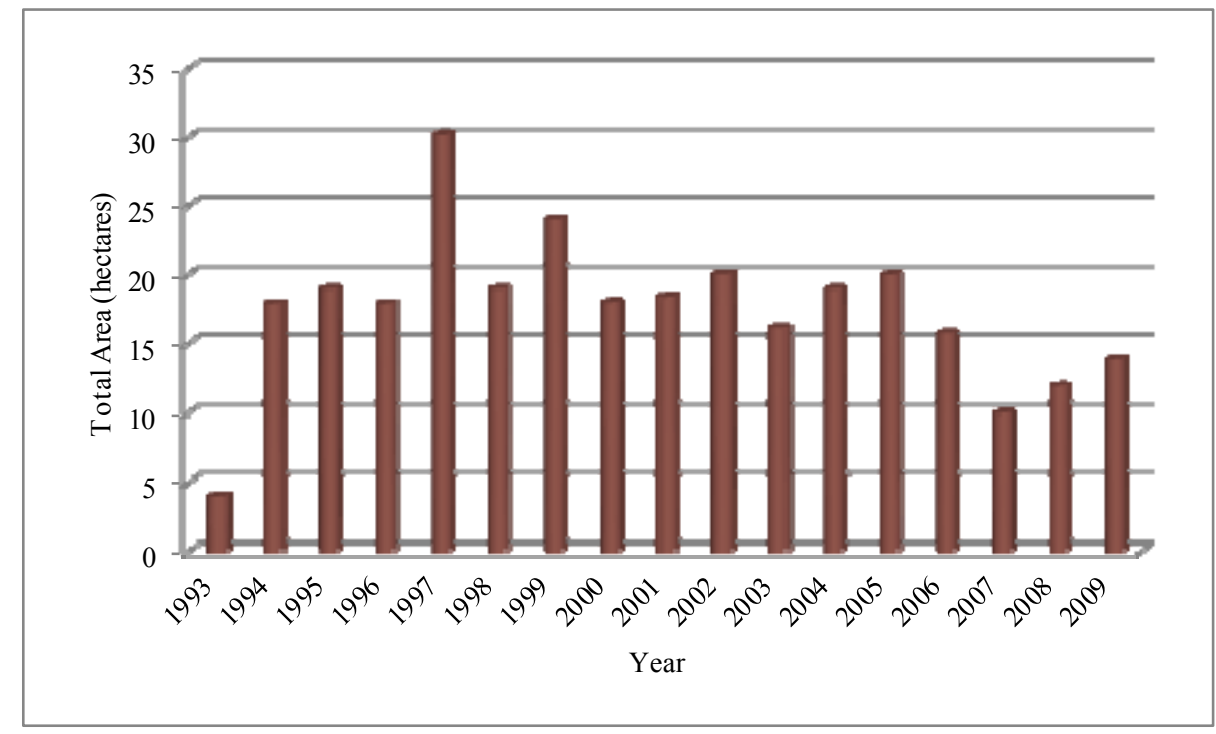

Figure 11. Total planted area from 1993 to 2009

Source: Created by the author, based on City Environment Office, Puerto Princesa City 2011

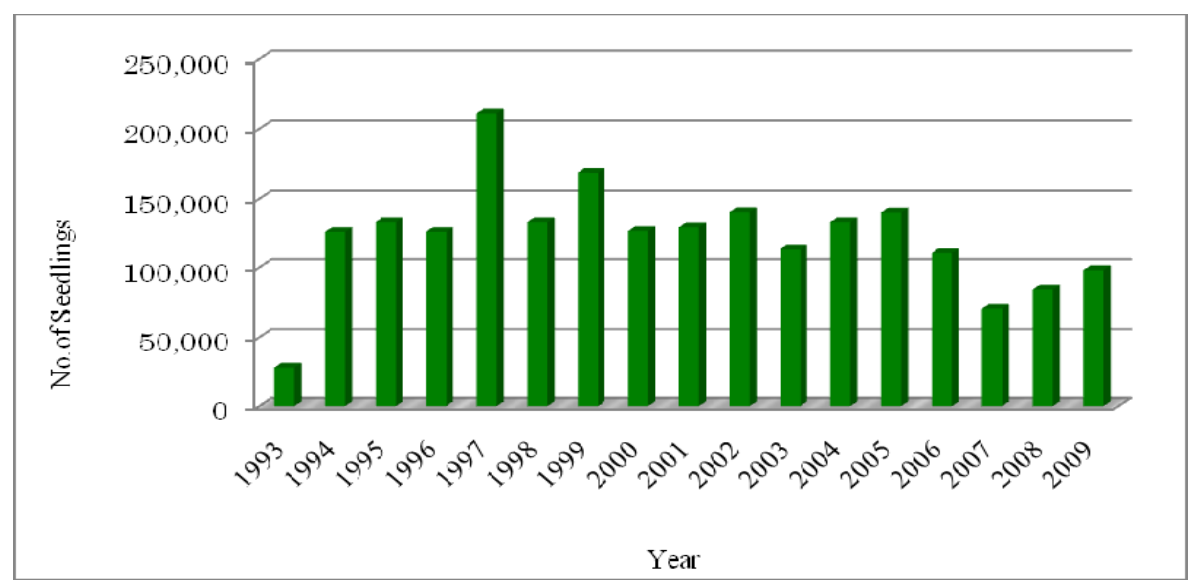

Figure 12. Number of seedlings planted from 1993 to 2009

Source: Created by the author, based on City Environment Office information, Puerto Princesa City 2011 
To determine the present situation and status of the previous kagueban plantations conducted at the Irawan Watershed, survival rate is estimated as shown in figure 13 (from 1993 to 1999 and 2005 to 2007) and at the Magarwak Watershed, shown in figure 14 (from 2000 to 2004), the City ENRO Office conducted a re-assessment from May 13 to 19, 2008.

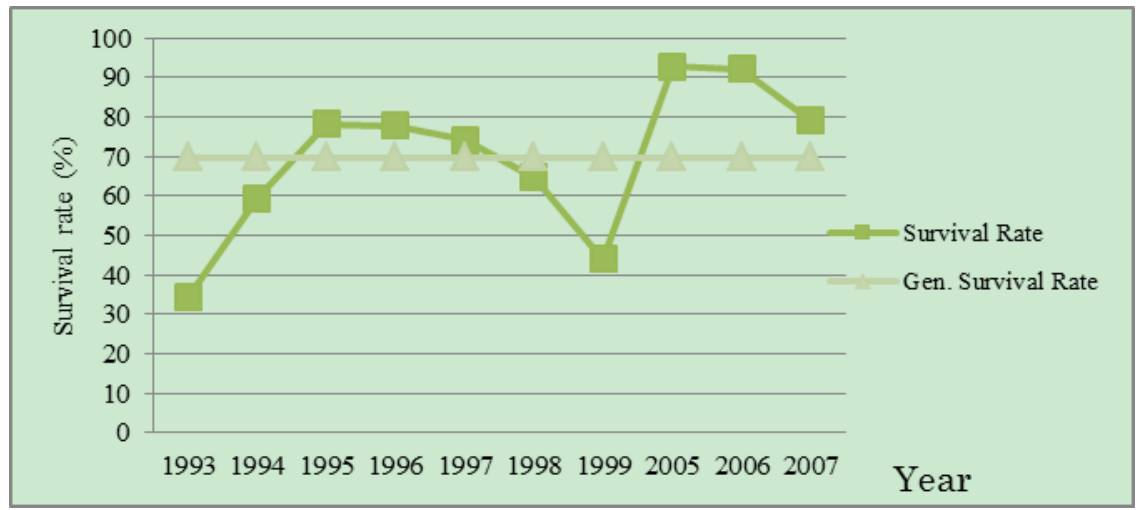

Figure 13. Survival rate of Irawan Watershed

Source: Created by the author, based on City Environment Office information, Puerto Princesa City 2011

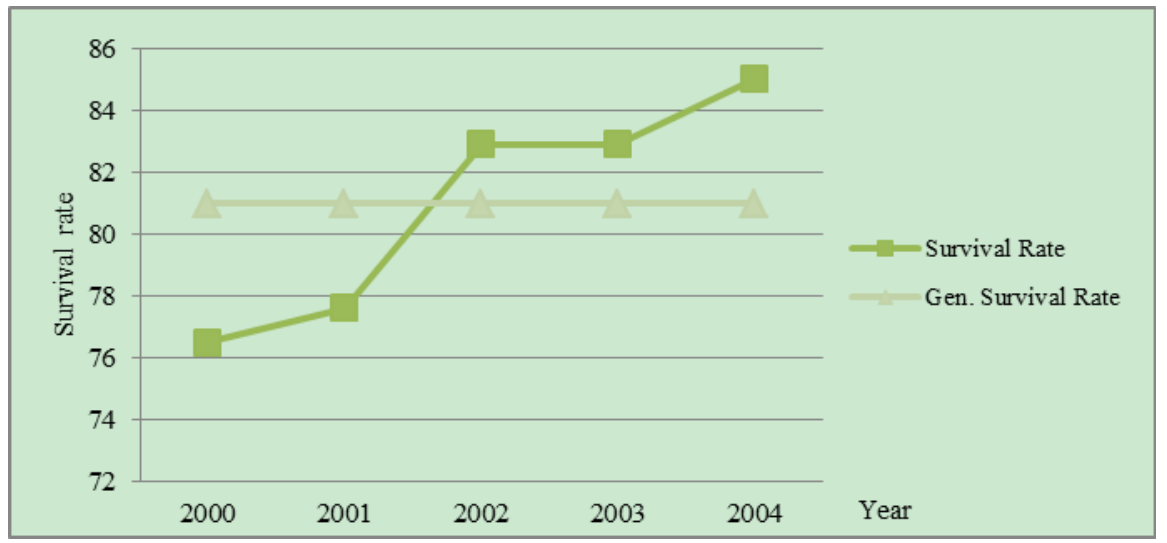

Figure 14. Survival rate at Magarawak

Source: Created by the author, based on City Environment Office information, Puerto Princesa City 2011

The City Environment Office conducts several monitoring and evaluation activities after each project is implemented. The average survival rate of Irawan watershed is 69.71 percent and for the Magarawak area it is 80.98 percent. Overall survival rate as of 2007 was 75.35 percent. In both areas five percent of the total area was selected as the sample area. There is a decrease in survival rate during PYAK 1993 to 1999 in Irawan Watershed. The possible reasons are trees planted during those years experienced negative external factors, such as storms (Norming, Milenyo, Lando, and Mina). Most of the trees planted were shallow rooted, and uprooted trees were observed within the areas. In the area of PYAK 1993, they have observed that higher elevation affects the growth of trees. Also the survival rate of the trees planted decreases if shallow rooted species are used. On the other hand, there was an increase in survival rate during PYAK 2004 to 2006 due, possibly, to factors such as continuous maintenance (replanting and clearing) and protection within the planted areas. Some trees are matured and already at harvestable age.

\section{Findings}

Javelosa 2010 states, "The story of Puerto Princesa Mayor Edward Hagedorn is common knowledge. Bad boy enters politics in 1992 for the first time in a place he didn't even grow up in. Bad boy turns around to transform first himself to follow an inner vision as he looked at a corrupted, polluted, dirty, poverty ridden backwater of a place. What his story, alongside that of Puerto Princesa's, the capital of the island of Palawan, has shown is the rise of the successful, progressive, visionary local leader with the passion and dedication towards the protection 
of the environment alongside countryside development". The continuation of the projects has been supported by the education campaign, mayor's efforts, governmental support, awareness level of the local community, voluntary based participation and social functions. The Pista Y Ang Kaguenban is not the only project that is highly performing and continuing due to the above reasons. There are various other environmental projects ongoing in Puerto Princesa. This massive tree plantation project is also in line with President Benigno Aquino III's vision of planting 1.5 billion trees over 1.5 million hectares nationwide (Graceffo, 2007). An official at DENR mentioned that every DENR office is required to produce 100,000 seedlings of fruit and forest trees. DENR provides the funding and local communities do planting as a volunteer activity. This is known as National Greening Program.

During formal and informal interviews, many respondents said that they have participated in every year in Pista Y Ang Kagueban tree planting project. Every respondent mentioned that people form a joint voluntary base for the event. Further they mentioned that people are aware of benefits to the environment and they join as responsible citizens. A monitoring team 'Bantayhubat' or 'forest watch' formed by the local community and paid by city hall, is an example of protecting the planted area. There are no illegal loggers within this area. Planted area is a public property owned by the government. Many respondents said to just leave it to nature once the plantation matured, with no harvesting required. No legal projects of harvesting are conducted in Puerto Princesa National policy prohibits cutting forest except for planted trees on a private property. Krishnapillay et al. 2007 introduced several lessons learned from CBFM activities based on studies conducted in South East Asia including Thailand, Indonesia, Vietnam, and Malaysia. The author has included these lessons and the attention given to CBFM by various internationally recognized documents, such as Our Common Future, Agenda 21 and The Future We Want in the following table. These lessons and emphases are compared with Pista Y Ang Kagueban, as shown in table 2.

Table 2. Lesson learned and international recognition on CBFM compared with Pista Y Ang Kagueban

\begin{tabular}{l} 
Lessons learned and International recognition \\
\hline An enabling policy and legal environment is \\
indispensable for the establishment and long term \\
management of tree plantations. Promoting \\
secured land tenure and right to involve in \\
decision making should be given national \\
legislative priority. \\
Institutional changes are needed to create a \\
climate of facilitation so that new technologies \\
and research findings can more easily be shared \\
between forest research institutions and plantation \\
investors. Establishing linkages among data \\
systems and sources need to be in place.
\end{tabular}

Existing degraded forests can be successfully rehabilitated using appropriate native and/or exotic species. There is also scope for mixed species plantations using both fast growing trees. Combating desertification and preventing erosion can be achieved through planting in degraded farm lands, high lands and barelands.

\section{Findings from Pista Y AngKagueban}

This plantation project is headed by local government and the planting area is owned by the government.

Therefore tenure rights for local community are not related to this project. City environment office conducts all evaluation and maintenance after every planting activity is taken place. This was started with the aim of securing water supply of the city.

Several research projects were conducted and data were collected by city environment office and findings are shared among forest rangers and other officials. There are no investors involved in this project but various stakeholders share research findings. Several training programs are being conducted in the area and also forest rangers participate in outside training activities.

There is no harvesting involved in this project. More than ten types of species are being planted in order to increase biodiversity. Most of the sites are degraded land or bare land and therefore plantation is not taking place near to well stocked natural forest. Throughout two decades, this planting area is protected from erosion and landslides. 
Preserving forest should be associated with the victims and agents of forest management.
Forest is properly managed with the support of local community, forest rangers and environmental authorities. Survival rates of planted trees are given much emphasis.

There are no harvesting activates being conducted and timber quality is not a concern of this project. The objective of this project is very clear and it is to enrich watershed area. Rules of the city prohibit harvesting in government owned land. properties as well as provide the samples for adequate marketing activities.

The local communities living in the vicinity of the project area need to derive significant benefits from the various activities of managing the plantation. Such activities include income from planting operations, silviculture, fire prevention and control and harvesting. Incorporating ecotourism activities will further increase economical benefits to local community.
Local community directly enjoys the benefit of getting employment as forest rangers and working in the plant nursery. There is no income for them based on harvesting. Also they are well aware of the increased water supply in the city and for many years they have not experienced any water shortage. Also biodiversity advantages and environmental protection including carbon sequestration are common knowledge among local citizens. There is no ecotourism activity involved in this planting activity. With strict monitoring it is a possibility to find alternative income for local citizens.

Source: Author 2013, adopted from Krishnapillay et al. 2007, Our Common Future 1987, Agenda 211992 and The Future We Want 2012.

\subsection{Puerto Princesa, a City in a Forest}

Mayor Edward Hagedorn has provided his excellent leadership for city government for more than 14 years. Since taking the mayorship, he has worked continuously on various projects, focused on environment, people, economy and education. These efforts has resulted that the Puerto Princesa city became a carbon neutral city. Montenegro 2012 states,

Puerto Princesa City is the first city in the country and Southeast Asia to be declared carbon-neutral under guidelines set by the Intergovernmental Panel on Climate Change. Puerto Princesa has a net carbon dioxide emission of 1,456 kilotons $(\mathrm{kt})$ and removes $1,662 \mathrm{kt}$ of $\mathrm{CO}_{2}$, technically making it carbon-negative. The emissions come from two sectors, electricity generation (52 percent) and road transportation (30 percent) with no emissions from industrial processes. Forests and croplands, on the other hand, account for nearly 99 percent of the removal of greenhouse gases.

The city has won several international awards and has repeatedly been voted as the "Cleanest and Greenest" city in the Philippines. Forest cover reduced greatly from 75 percent in 1976 to less than 52 percent in 1992 (Mayor Hagedorn, 2010). But today, with 75 percent forest cover, Puerto Princesa is one of the largest sanctuaries of old growth and replanted forest in the world (Graceffo, 2007). Forest cover is continuously increasing in Puerto Princesa, as shown in figure 15, and by 2010 it has reached 185,406 hectares. 


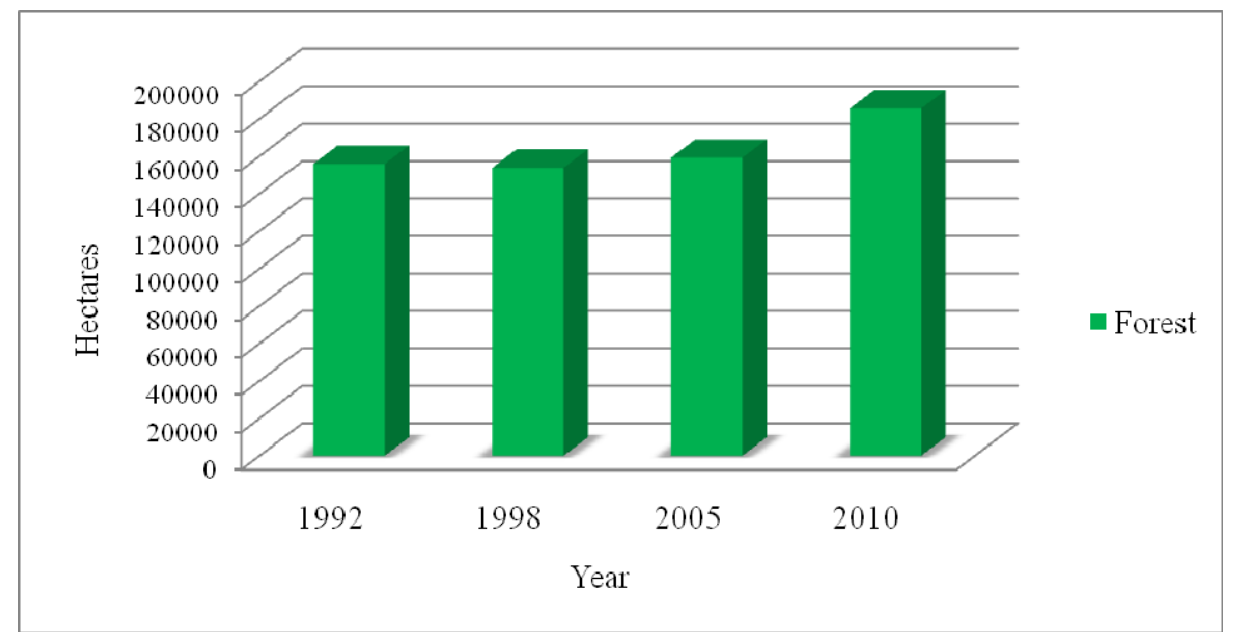

Figure 15. Forest cover in Puerto Princesa

Source: Created by the author, based on PCSD 2010 and City Information Office 2013

Feast of the Forest massive tree planting project is an example of a forestation project conducted successfully for the last two decades and which will continue in the years to come. In any development activity, the city mayor and officials keep the environment as the centerpiece in order to maintain their city as a "City in the Forest." Before Mayor Hagedorn came to power, the city was filled with garbage. The mayor's first project was moving garbage and creating the first engineered sanitary landfill in the Philippines (Graceffo, 2007). Citizens are busy with leisure and sports activities and the crime rate has also dropped closer to zero. The mayor has established 300 public Montessori schools and several medical centers to guarantee education and health for the local community. Tourism activities consistent with environment protection are integrated with other social development programs in the city. This integration, linking cleanliness, beautification, sanitation, save the sea, save the air, information and education, is known as "Oplan Linis Plan" (Graceffo, 2007).

During a presentation in 2010, Mayor Hagedorn stated, "Success factors as: active participation and involvement of the various sectors of the community, economic impact of the policies and programs implemented were addressed, involved stakeholders in the policy/program development and implementation, coordination and transparency were maintained at various levels of implementation and political will and full commitment of the highest policy maker". Based on the author's observations and interviews, it would appear that project continuation and continuous participation are based on factors such as diversity of knowledge about forestry among students, elders and policy makers. Forestry education programs and sustainable forest management programs are integrated with social, economic and biological aspects, government involvement, funding and leadership role, with necessary law enforcement and implementation supporting further continuation. Former head of city ENRO mentioned that it is difficult to follow the Clean Development Mechanism (CDM), as defined in the Kyoto Protocol, because the international guidelines are very strict for a developing country to adopt. It is a huge disadvantage and a proper mechanism to measure carbon sequestration is needed. Therefore, the city is losing substantial amount of potential economic gains.

For further development of the project, a much bigger site needs to be used for the community to plant more trees. When much space and seedlings are provided closer to planting area, there is a tendency that one person may plant several trees. The local community needs to be made aware of the benefits of planting trees by using television, radio, newspapers and hoardings. Also, conducting poster campaigns in educational institutes and other organizations will be another mode of inviting more people. Free distribution of the seedlings by the government and providing some funds from the government will also increase the interest. Many organizations celebrate their important dates by planting trees and City ENRO provides seedlings. By making planting trees a social event, many people will join as representatives of their respective organizations. Continuous planting projects need to be implemented and strict monitoring for protection is required further to increase the survival rate of the planted trees. People's organizations have the responsibility of protecting their local area, and forest rangers paid by DENR or city government, are also working to monitor the area. Manpower, such as forest rangers, is in short supply due to low budget. 


\section{Conclusion}

Annual community based forest plantation projects, coupled with other environmentally integrated projects, show ingredients of sustainability, such as government involvement, necessary law enforcement, political will, proper leadership, community involvement, alternative livelihoods, education campaign, involvement of all local and national organizations, and willingness of local communities. Former Mayor Edward Hagedorn worked continuously during the last two decades, focusing on projects that support the environment, education and welfare in Puerto Princesa. Various projects have been conducted in order to enhance the capacity of local citizens. Global and Philippines forestry shows a negative growing trend. Puerto Princesa City provides very unique and impressive examples for forestation, forest management and protection. There are both qualitative and quantitative data, as discussed in the paper, showing that the forest cover has continued to gain for the last two decades. In Puerto Princesa, local citizens are well aware of the benefits of being environmentally sound and are proud of their achievements. For its commitments by leadership and community, Puerto Princesa City has won a variety of international awards. The city was recognized as the "Cleanest and the Greenest City" in the Philippines, including the achievement of becoming the first carbon neutral city of the ASEAN region. "Puerto Princesa is a jewel of a case study of the success of a place that actually works and can point to a direction that other local government units and the whole country can take" (Javelosa, 2010).

\section{Acknowledgments}

A special thanks to Dr. Ramon and Dr. Patrick of PSU, Former Mayor Edward Hagedorn, Current Mayor Bayron, City Office staff, City Enro staff, PCSD staff, and all local community members who provided support during field visits. Also, a special thanks to Professor Miyoshi Professor Sanga and Professor Susumu of APU for continuous advice, all other staff members at Ritsumeikan Asia Pacific University for continuous support and Professor Faulkner for help in editing this research paper. Also I would like to thank Kobayashi International Scholarship Foundation for their continuous financial support since 2012.

\section{References}

Bautista, G. M. (1990). The forestry crisis in the Philippines: Nature, causes and issues. The Developing Economies, 28(1), 67-94. http://dx.doi.org/10.1111/j.1746-1049.1990.tb00175.x

Brown, K. (2003). Three challenges for a real people-centred conservation. Global Ecology \& Biogeography, 12, 89-92. http://dx.doi.org/10.1046/j.1466-822X.2003.00327.x

Bunge, F. M. (1984). Philippines, a Country Study. The American University, Washington, DC.

City Environment Office. (2011). Love Affair with Nature and Pista Y Ang Kagueban: internal communaication document. Puerto Princesa City: Unpublished.

City Information office. (2010). Puerto Princesa. Interview using an internal communication document,City hall, Puerto Princesa City.

City Information office. (2013). Puerto Princesa. Interview using an internal communication document, City hall, Puerto Princesa City.

City Tourism office. (2012). Puerto Princesa City Tourism Situationer, City Coliseum, Puerto Princesa City.

Contreras H. A. (2000). The underlying causes of forest decline. CIFOR Occasional Paper No. 30. Bogor: Center for International Forestry Research.

Dawning, S. L., Iverson, L. R., \& Brown, S. (1993). Rates and patterns of deforestation in the Philippines: application of geographic information system analysis. Forest Ecology and Management, 57, 1-16. http://dx.doi.org/10.1016/0378-1127(93)90158-J

De la Cruz, E. (1941). The socio-economic significance of the Philippine forest. The Philippine Journal of Forestry, 4(2), 141-160.

Department of Environment and Natural Resources (DENR). (1989). Community forestry program manual of operation. In: Policies, Memoranda and Other Issuances on the National Forestation Program. Department of Environment and Natural Resources, Quezon City, Philippines. pp. 172-187.

Department of Environment and Natural Resources (DENR). (2003). Forest Management Bureau. Retrieved September 8, 2013, from http://forestry.denr.gov.ph/reqcbfma.htm

Food and Agriculture Organization of the United Nations. (2006). Global Forest Resources Assessment 2005, Progress towards sustainable forest management. Rome, Italy. 
Food and Agriculture Organization of the United Nations. (2010). Global Forest Resources Assessment 2010 Terms and Definitions. Rome, Italy.

Food and Agriculture Organization of the United Nations. (2012). State of the World's Forests. Rome, Italy.

Food and Agriculture Organization. (1978). Forestry for local community development. FAO Forestry Paper No. 7, Rome, Italy.

Food and Agriculture Organization. (1989). Review of forest management systems of tropical Asia: case studies of natural forest management for timber production in India, Malaysia and the Philippines. Rome, Italy.

Food and Agriculture Organization. (2000). Global forest resource assessment. Main report 2000. FAO Forestry Paper 140. Rome, Italy.

Food and Agriculture Organization. (2001). State of the world's forests. Rome, Italy.

Forest Management Bureau. (2005). Philippine Forestry Statistics. Department of Environment and Natural Resources, Quezon City, Philippines.

Ganapin D. (1987). The timber trade of the Philippines. Forest resources crisis in the Third World. Sabahat Alam Malaysia.

Garrity, D. P., Kummer, D. M., \& Guiang, E. S. (1993). The upland ecosystem in the Philippines: alternatives for sustainable farming and forestry. National Academy Press, Washington, D. C.

Graceffo, A. (2007). Philippines: The Feast of Forest and Crocodiles. Retrieved July 12, 2013, from $\mathrm{http} / / /$ www.escapeartist.com/efam/91/art_phillipines.html

Graceffo, A. (2007). Puerto Princesa: The Philippines' Cleanest and Greenest City. Retrieved July 12, 2013, from http://www.wildasia.org/main.cfm/RTI/Puerto_Princesa

Guiang, E., Salve, B., \& Borlagdan, J. M. P. (2001). Community-Based Forest Management in the Philippines: A Preliminary Assessment. Institute of Philippine Culture, Ateneo de Manila University, Quezon City.

Guillermo, M., \& Prabhu, R. (2005). Combining participatory modeling and multi-criteria analysis for community-based forest management. Forest Ecology and Management, 207(1-2), 145-156. http://dx.doi.org/10.1016/j.foreco.2004.10.024

Hagedorn, E. (2010). Puerto Princesa City. Presentation at the welcome dinner for newly married couples.

Hagedorn, E. (2012). Puerto Princesa City. Presentation at the thanks giving and information sharing dinner for city officials.

Javelosa, E. (2010). Feast of the forest. Retrieved July 18, 2013, from http://www.philstar.com/allure/593897/feast-forest

Jayagoda, D. (2011). The Performances of Sustainable Environmental Development Projects (Mangrove Plantation) in Puerto Princesa City, Palawan - Philippines. Master's thesis, Ritsumeikan Asia Pacific University of Japan.

Jayagoda, D. (2012). Valentine's Day and the Environment: A "Love Affair with Nature", Voices from the sylff community. Retrieved October 2, 2013, from http://www.tokyofoundation.org/sylff/9227

Krishnapillay, B., Michael, K., Lucrecio, L. R., \& Don, L. (2007). Rehabilitation of Degraded Forest Lands in Southeast Asia A Synthesis Keep Asia Green, Southeast Asia. Edited by Don Koo Lee. International Union of Forest Research Organizations (IUFRO), World Series Vol. 20-I.

Kummer, M. (1992). Deforestation in the Postwar Philippines, University of Chicago, Geography Research Papers.

Lasco, R. D., Visco, R. G., \& Pulhin, J. M. (2001). Secondary forests in the Philippines: formation and transformation in the $20^{\text {th }}$ century. Journal of Tropical Forest Science, 13(4), 652-670.

Montenegro, A. (2012). Puerto Princesa's 'Feast of the Forest' sees 2M trees planted. Retrieved August 19, 2013, from http://www.interaksyon.com/lifestyle/puerto-princesa\%E2\%80\%99s-\%E2\%80\%98feast-of-the-f orest $\% \mathrm{E} 2 \% 80 \% 99$-sees-2m-trees-planted

Ooi, J. B. (1987). Depletion of the forest resources in the Philippines. Institute of Southeast Asian Studies, Singapore. Field Rep. Ser. No. 18.

Quintos, M. M. (1989). The log export restriction policy and the development of forest industries in the Philippines. Master's Thesis. The Australian National University, Canberra, Australia. 
Rebugio, L. L., Cruz, R. V. O., Carandang, W. M., Tolentino, E. L., de la Cruz, L. U. Lasco, R. D., ... Camacho, L. D. (2005). Forest restoration in the Philippines. A review of research anddevelopment initiatives. University of the Philippines Los Baños, Office of the AKECOP Coordination in the Philippines, College of Forestry and Natural Resources, College, Laguna.

Rebugio, L. L., Pulhin, J. M., Carandang, A. P., Peralta, E. O., Camacho, L. D., \& Bantayan, N. C. (2007). "Forest Restoration and Rehabilitation in the Philippines." Edited by Don Koo Lee. International Union of Forest Research Organizations (IUFRO) World Series Vol. 20-I Keep Asia Green, "Southeast Asia." Volume I.

United Nations Conference on Environment \& Development. (1992). "AGENDA 21”, Rio de Janerio, Brazil, 3 to 14 June 1992.

United Nations. (1987). Our Common Future. Report of the World Commission on Environment and Development.

United Nations. (2012). "The Future We Want" UN Web Services Section, Department of Public Information. Retrieved November 6, 2013, from http://www.un.org/en/sustainablefuture/

Wallace, M. (1993). Philippine forests: private privilege or public preserve? IESAM Bulletin, XIII(3-4). UPLB, College, Laguna, Philippines.

Westoby, J. (1989). Introduction to World Forestry. Basil Blackwell, Oxford.

\section{Copyrights}

Copyright for this article is retained by the author(s), with first publication rights granted to the journal.

This is an open-access article distributed under the terms and conditions of the Creative Commons Attribution license (http://creativecommons.org/licenses/by/3.0/). 